\title{
Application of the Principles of International Environmental Law in the domestic legal System of Bangladesh: A Critical Study on the legal framework and the position of judiciary
}

\author{
M. Z. Ashraful \\ Faculty of Legal Studies, South Asian University, New Delhi, India
}

\begin{abstract}
There are some basic principles of international Environmental Law and some of them are now customary international law. These principles should implement in the domestic legal system for the sake of environmental interest. But there is a problem of the countries like Bangladesh to implement these principles because of inadequate national legal mechanism. In this arena the judiciary of these countries can play an important role by incorporating these principles with the harmonious explanation of the existing legal framework. However it is important to mention here that Bangladesh is also trying to adopt such principles by either amending its constitution or by enacting new national legislation regarding environmental protection. So this paper seeks to analyze briefly various principles of international environmental law and the application of the principles of International Environmental Law in the domestic legal system of Bangladesh. In some extent this paper has tried to describe the environmental synopsis of Bangladesh. As little of the study suggests, the main purpose is to expose what are the legal stipulations as regards the principles of International Environmental Law in the national law of Bangladesh and also in some cases this paper has taken initiative to compare with other south Asian Countries regarding implementation of environmental principles in the domestic legal system. An attempt has been taken by this paper to examine the role of the Judiciary relating to the implementation of such principles.
\end{abstract}

Key Words: Bangladesh, Constitution, International Environmental Law, Judiciary, Legal Framework, Principle, Protection.

\section{Introduction}

The most important aspect of life is environment. Survival, production, reproduction, growth, development etc. of the living organism are finished by the environment. It is considered that environment is a common concern of all human being in the world. So it is mandatory to save from harm the environment because without healthy and clean environment how can we imagine our healthy and happy life. So it can be said that the protection of the environment is comparable to the protection of life. Now a day it is argued that right to healthy and clean environment is related to the right to life. So for the protection of environment there are some basic principles of international environmental law which need to be incorporated in the domestic legal system for the interest of better protection of environment. But the crucial point is that nation states are very much reluctant to incorporate these principles into their national legal system directly. Bangladesh is not the exception although it is in vulnerable condition for environmental devastation in many aspects. There are lots of non - governmental organizations in Bangladesh are rising to make awareness regarding environmental issues among the nation, government. They are trying to create pressure on government to make necessary implementing environmental friendly national legislation and also there is international obligation regarding this. However, Bangladesh is also trying to incorporate environmental friendly legislation, policy for the healthy and clean environment. On the other hand these legislations, policies, initiatives etc. are not an adequate amount of implementing the principles international environmental laws and also environmental conventions, covenant, protocol etc. where Bangladesh is a signatory country. In some extent the judiciary is also trying to explain for the incorporation of these principles in the national level directly or indirectly. It is important to note that Bangladesh is in at risk situation for a variety of environmental changes. So, it needs to be implemented such recognized principles and international environmental law regarding environmental protection and development.

\section{General Synopsis On The Principles Of International Environmental Law}

In point of fact, there is no precise instrument where all the principles of international environmental law have codified but the principles regarding environmental issues are found in the different international declarations, treaty, and conventions e.g. Stockholm Declaration, 1972 and Rio de Janerio Declaration, 1992 and also the customary international law one of the most important source of international law. It is important to mention here that most of the international declarations, treaty or conventions on the subject of environmental 
concerns are soft law instruments and it is also alleged that the soft law is developing as a main source of environmental law at the present time. The principles of international environmental law may be grouping into two ways; one is those general principles of international law which are related to environmental issues and the other is the principles of international environmental law in the strict sense. The first group may include the principle of state sovereignty ; the principle of permanent sovereignty over natural resources; the principle for the management of a shared natural resources and common property; common heritage of mankind; and principle of State responsibility; equal access to administrative and judicial proceedings;

On the other hand the most referred and significant principles of environmental law include the following emerging principles and concept $^{1}$ - sustainable development, integration and interdependence; interGenerational and intra-generational equity; responsibility for trans-boundary harm; transparency, public participation and access to information and remedies; cooperation and common but differentiated responsibilities; precaution; prevention; polluter pays principle; access and benefit sharing regarding natural resources; common heritage and common concern of humankind; and good governance;

\section{Environmental Synopsis Of Bangladesh}

Bangladesh faces a variety of environmental problems because of geographical location, over population, poor economic condition, ineffectual resources management and lack of legal and institutional framework. Due to its environmental problems Bangladesh recognizes the vital importance of participating in the global attempts to halt the process of environmental deterioration. Bangladesh was actively involved in the proceedings of the UNCED, signed the Rio Declaration and endorsed Agenda 21. This reflects the strong commitment of Bangladesh towards promoting environmental management and sustainable development. ${ }^{2}$ Bangladesh is bordered of its three parts by India and southeastern part by Myanmar and south part by Bay of Bengal. Bangladesh possesses enormous area of wetlands including rivers and streams, freshwater lakes and marshes, haors, baors, beels ${ }^{3}$, water storage reservoirs, fish ponds, flooded cultivated fields and estuarine systems with extensive mangrove swamps. ${ }^{4}$ It is important to mention here that Bangladesh is a signatory state of the Ramsar Convention on wetlands ${ }^{5}$ and it has declared two wetlands as Ramsar site. ${ }^{6}$ There are about 405 rivers in Bangladesh of which 57 are trans-boundary Rivers. ${ }^{7}$ But until now Bangladesh is not a signatory country of the Convention on the Protection and Use of Transboundary Watercourses and International Lakes. ${ }^{8}$ Bangladesh generally enjoys sub-tropical monsoon climate. The average annual rainfall varies from $1400 \mathrm{~mm}$ to $4500 \mathrm{~mm} .{ }^{9}$ Bangladesh is rich in flora and fauna, including nearly 250 indigenous species of mammals, 750 types of birds, 150 kinds of reptiles and amphibians, and 200 varieties of marine and freshwater fish. The rhesus monkey is common, and gibbons and lemurs are also found. ${ }^{10}$ Overall it has about 5000 species of flowering plants and 1500 species of fauna. ${ }^{11}$ It is also a signatory state of Convention of Biological diversity and Nagoya Protocol as well. ${ }^{12}$ The forests cover about $17 \%$ of the total land area of Bangladesh. ${ }^{13}$ The Ministry of Environment and Forests (MoEF) of Bangladesh won the Earth Care Award 2012 (sponsored by the Times of India) for spearheading the Least Developed Countries Fund (LDCF) (LDCF) project "Community Based Adaptation to Climate Change through Coastal Afforestation in

\footnotetext{
${ }^{1}$. Lal Kurukulasuriya \& Nicholas A. Robinson Training Manual on International Environmental Law (UNEP/Earthprint Publishing 2006) 23-24 <http://www.unep.org/environmentalgovernance/Portals/8/documents/training_Manual.pdf > accessed 2 February 2014

2.BANGLADESHCOUNTRY PROFILEIMPLEMENTATION OF AGENDA 21:REVIEW OF PROGRESS MADE SINCE THEUNITED NATIONS CONFERENCE ONENVIRONMENT AND DEVELOPMENT, 1992 (1997)

$<$ http://www.un.org/esa/earthsummit/bang-cp.htm> accessed 5 February 2014

3. haors, baors, beels are types of wetlands.

4. Bangladesh Water Development Board 〈http://www.bwdb.gov.bd/index.php?option=com content\&view=article\&id=104\&Itemid=94〉 accessed 5 March 2014

5. Contracting Parties to the Ramsar Convention on Wetlands (2014)

<http://www.ramsar.org/cda/en/ramsar-about-parties-parties/main/ramsar/1-36-123\%5E23808 4000_0 > accessed 15 April 2014

6 . The List of Wetlands of International Importance (2014)

$<$ http://www.ramsar.org/pdf/sitelist.pdf > accessed 15 April 2014

7 . Joint Rivers Commissions of Bangladesh, Ministry of Water Resources <http://www.jrcb.gov.bd/> accessed 10 April 2014

${ }^{8}$. Convention on the Protection and Use of Transboundary Watercourses and International Lakes (adopted 17 March 1992, entered into force 6 October 1996)

$<$ https://treaties.un.org/pages/ViewDetails.aspx?src=TREATY\&mtdsg_no=XXVII-5\&chapter=27\&lang=en> accessed 8 April, 2014

9. Final Report - Global Environment

$<$ http://www.thegef.org/gef/sites/thegef.org/files/documents/document/Bangladesh\%20NCSA\%20Report.pdf > accessed 12 April 2014

${ }^{10}$.Geography of Bangladesh - Bangla2000 < http://www.bangla2000.com/bangladesh/geography.shtm > accessed 2 February 2014

${ }^{11}$. Supra Note 9

${ }^{12}$. Convention on Biological Diversity (adopted 5 June 1992, entered into force 29 December 1993) List of Parties <http://www.cbd.int/information/parties.shtml> 15 February 2014

13. Monitoring, Assessment \& Reporting on Sustainable Forest Management (MAR-SFM) 〈http://ulterious.com/MAR-

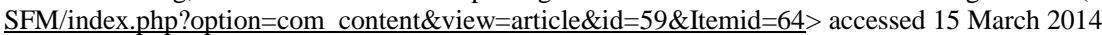


Bangladesh". ${ }^{14}$ Bangladesh has prepared a National Phase out Plan of Ozone Depleting Substances, which is currently being implemented with assistance from the Montreal Multilateral Fund. ${ }^{15}$ Bangladesh has signed a lots of treaty, convention and protocol relating to environmental issues for instance - International Plant Protection Convention (Rome, 1951); International Convention for the Prevention of Pollution of the Sea by Oil (London, 1954 (as amended on I I April 1962 and 21 October 1969.); Plant Protection Agreement for the South East Asia and Pacific Region (as amended) (Rome, 1956.); Treaty Banning Nuclear Weapon Tests in the Atmosphere, in Outer Space and under Water (Moscow, 1963.); Treaty on Principles governing the Activities of States in the Exploration and use of outer Space Including the Moon and Other Celestial Bodies (London, Moscow, Washington, 1967.); International Convention Relating to Intervention on the High Seas in Cases of Oil Pollution Casualties (Brussels, 1969.); Convention on Wetlands of International Importance especially as Waterfowl Habitat (Ramsar, 197 1) ("Ramsar Convention").;Convention on the Prohibition of the Development, (Biological) and Toxic Weapons, and on Their Destruction (London, Moscow, Washington, 1972.); Convention Concerning the Protection of the World Cultural and natural Heritage (Paris, 1972.); Convention on International Trade in Endangered Species of Wild Fauna and flora (Washington, 1973.) ("CITIES Convention"); Vienna Convention for the Protection of the Ozone Layer (Vienna, 1985.); Montreal Protocol on Substances that Deplete the Ozone Layer (Montreal 1987.); London Amendment to the Montreal Protocol on Substances that Deplete the Ozone Layer (London, 1990. Copenhagen Amendment.); Convention on Early Notification of a Nuclear Accident (Vienna, 1986.); Convention on Assistance in the Case of a Nuclear Accident of Radiological Emergency (Vienna, 1986.); Agreement on the Network of Aquaculture Centres in Asia and the Pacific (Bangkok, 1988.); Basel Convention on the Control of Transboundary Movements of Hazardous Wastes and Their Disposal (Basel, 1989.); International Convention on Oil Pollution Preparedness, Response and Cooperation (London, 1990.); United Nations Framework Convention on Climate Change (New York, 1992); International Convention to Combat Desertification, (Paris 1994.); Convention on the Prohibition of Military or Any Other Hostile Use of Environmental Modification Techniques, (Geneva, 1976.); Agreement Relating to the Implementation of Part XI of the United Nations Convention on the Law of the Sea of 10 December 1982 ish Stocks (New York, 1994.); Agreement for the Implementation of the Provisions of the United Nations Convention on the Law of the Sea of 10 December 1982 Relating to the Relating to the Conservation and Management of Straddling Fish Stocks and Highly Migratory Fish Stocks (New York, 1995.); Convention on the Prohibition of the Development, Production, Stockpiling and Use of Chemical Weapons and on their Destruction (Paris, 1993.); United Nations Convention to Combat Desertification in those Countries Experiencing Serious Drought and/or Desertification, Particularly in Africa (Paris, 1994.); Convention on Nuclear Safety (Vienna, 1994.).; ${ }^{16}$

\section{Legal Framework Concerning The Principles Of International Environmental Law In Bangladesh}

As many as 106 countries of the world have incorporated environment related provisions in their Constitution. While some of the state constitutions have mentioned environment in the preamble, others have opted to mention environment either as right or duty or as a matter of public interest. ${ }^{17}$ Among the south Asian countries Nepal is the best example to incorporate environmental related provision in the interim constitution as fundamental right. It is provided that every person shall have the right to live in clean environment. ${ }^{18}$ It is also said in the directive principles of state policy that the State shall make necessary arrangements to maintain clean environment. The State shall give priority to the protection of the environment, and also to the prevention to its further damage due to physical development activities by increasing the awareness of the general public about environmental cleanliness, and the State shall also make arrangements for the special protection of the environment and the rare wildlife. Provision shall be made for the protection of the forest, vegetation and biodiversity, its sustainable use and for equitable distribution of the benefit derived from it. ${ }^{19}$ Another south Asian country Bhutan also has incorporated a long provision heading environment in its constitution and said that every Bhutanese is a trustee of the kingdom's natural resources and environment for the benefit of the present and future generations and it is the fundamental duty of every citizen to contribute to

14. Global Environment Faculty 〈http://www.thegef.org/gef/news/bangladesh-wins-earth-care-award-2012-ldcf-project〉 accessed 10 February 2014

15 Supra Note 2

16. Ministry of Environment and Forest, Government of the People's Republic of Bangladesh <http://www.moef.gov.bd/html/protocol/protocol main.html> accessed 18 February 2014

17. Syeda Rizwana Hasan 'APPLICATION AND REFORM NEEDS OF THE ENVIRONMENTAL LAWS IN BANGLADESH'(2005) 9(85) BJL

<http://www.biliabd.org/article\%20law/Vol-09/Syeda\%20Rizwana\%20Hasan.pdf> accessed 5 February 2014

18 . Interim Constitution of Nepal art 16(1)

${ }^{19}$. Ibid art $35(5)$ 
Application of the Principles of International Environmental Law in the domestic legal System ....

the protection of natural environment, conservation of the rich biodiversity of Bhutan and prevention of all forms of ecological degradation including noise, visual and physical pollution through the adoption and support of environment friendly practices and policies. ${ }^{20}$ On the other hand before $15^{\text {th }}$ amendment there was no express provision in the constitution of Bangladesh regarding environmental issues or principles of environmental law. The fundamental rights, the preamble or the state policies enshrined in the Constitution did not expressly mention any right to healthy or clean environment. However $15^{\text {th }}$ amendment is a landmark amendment in the history of recognition of the environmental concern in the constitution of Bangladesh. According to the constitution of Bangladesh the state shall endeavor to protect and improve the environment and to preserve and safeguard the natural resources, bio-diversity, wetlands, forest and wild life for the present and future citizens. ${ }^{21}$ But this environmental friendly provision is incorporated in the part of fundamental principles of state policy of the constitution which are not directly enforceable by the court of law and hence this provision is covered the way for making or interpreting laws regarding environmental protection. ${ }^{22}$ Although it is not a fundamental right as Nepal but in some extent it recognizes the principle of sustainable development which is a great part of environmental protection and principle of protection. After the independence of Bangladesh the first step of the new born country in the interest of preserving and conserving environment was Water Pollution Control Ordinance, $1973 .{ }^{23}$ Later, Pollution Control Ordinance was made for the overall protection from the pollution of environment in 1977. ${ }^{24}$ Then in 1985 the Department of Pollution Control was established but in 1989 it was restructured and renamed into the Department of Environment. ${ }^{25}$ In 1989, the new ministry The Ministry of Environment and Forest was established ${ }^{26}$ and then lots of NGO emerged with environmental protection and preservation as their main goal. Whatever the progress was made in this period the concrete development of environmental protection in Bangladesh was recognized with the adoption of the Environmental Policy, 1992 and the Environmental Action Plan, 1992. The National Environmental Policy 1992 has been followed by a good number of sectors - specific policies to achieve the broad goal of the National Environment Policy. ${ }^{27}$ These policies include: Forestry Policy 1994, Fisheries Policy 1998, Agriculture Policy 1999, National Water Policy 1999, Industrial Policy 1999, National Health Policy 2005, National Food Policy, Urban Transport Policy, Livestock Development Policy 1992 National Land Use Policy 2001 and National Energy Policy 2004. ${ }^{28}$ Following the guideline of that national environmental policy and action plan Environmental Conservation Act, 1995 was enacted for environment conservation, the improvement of environmental standards, and control and mitigation of environmental pollution. ${ }^{29}$ The Bangladesh Environment Conservation Act, 1995 provides that director general of the department of environment can oblige a person to pay where such person is responsible directly or indirectly for the injury to the ecosystem or person or group of persons. ${ }^{30}$ To ensure the access to environmental justice Environment Court Act, 2010 has also been passed by the parliament. There are many other laws which have been enacted in last 20 years for the protection of environment such as Disasters Management Act, 2012; Wildlife (Preservation and Protection) Act, 2012; Forest Act, 1927; the Building Construction Act, 1952; Brick Burning Control Act, $1989 .{ }^{31}$

\section{Applicability Of Principles Of International Environmental Law In The Domestic Legal System And The Role Of Judiciary In Bangladesh}

As like other common law countries, Bangladesh follows dualistic approach as regards the ratification and incorporation of international treaty within the domestic law. ${ }^{32}$ There is no express constitutional provision regarding the application of international laws in national courts of Bangladesh. Beside article 25 of the constitution of Bangladesh only one provision regarding treaty status is that all treaties with foreign countries shall be submitted to the president, who shall cause them to be laid before parliament. ${ }^{33}$ Courts in Bangladesh

\footnotetext{
20. Constitution of the Kingdom of Bhutan 5(1)

21 . Constitution of the People's Republic of Bangladesh art $18 \mathrm{~A}$

22. Constitution of the People's Republic of Bangladesh 8(2)

23. Gazi Saiful Hasan and Sheikh Ashrafur Rahaman Principles of International Environmental Laws: Application in National Laws of Bangladesh' (2013) 11 BVRJ <http://www.bv-f.org/vol_11.html> accessed 17 February 2014

24 . Ibid

25. Md Iqbal Hossain, International Environmental Law Bangladesh Perspective (2 ${ }^{\text {nd }}$ edn, Ain Prokashona 2008) P 412

26. Ministry of Environment and Forest, Government of the People's Republic of Bangladesh <http://www.moef.gov.bd/html/about/about_us.html> accessed 18 February 2014

27. Supra Note 25 Page 413

28 . Supra Note 25 Page $413-414$

${ }^{29}$ Bangladesh Environment Conservation Act 1995 <http://www.moef.gov.bd/html/laws/env law/153-166.pdf> accessed 5 February 2014

30 . Ibid, S 9

31. Supra Note 23

${ }^{32}$. M. Z. Ashraful, 'Status of Treaty under the Constitution of SAARC Countries: An Approach towards Bangladesh and India Perspective' (2014) 5(2) MCSER <http://www.mcser.org/journal/index.php/mjss/article/viewFile/1968/1967> accessed 10 February 2014

${ }^{33}$. Constitution of the People's Republic of Bangladesh art $145 \mathrm{~A}$
} 
cannot enforce treaties even if ratified by the state. They must be incorporated in the municipal legislation. ${ }^{34}$ It is only possible for the domestic court to apply international laws, principles, treaties, conventions etc if these are incorporated in the national laws. However, the court does utilize international principles, conventions and covenants as an aid to interpretation of the provisions of Part III of the constitution, particularly to determine the right to life and the right to liberty, but not to enumerate within the Constitution. If there is no clear provision in the domestic laws in any particular case then the national courts may take the principles/provisions of international law as the guideline and the supreme court of Bangladesh has referred these non binding international instrument in various case e.g. Zahida Ahmed (Liza) vs. Syed Noor Uddin Ahmed and another, ${ }^{35}$ Tayazuddin and another vs. Bangladesh, ${ }^{36}$ Bangladesh and another vs. Hasina and another, ${ }^{37}$ and also in the case of Dr. Mohiuddin Farooque v. Bangladesh ${ }^{38}$, where the right to life protected under the constitution was discussed by reference to the resolution of the World Health Organization. ${ }^{39}$ However, because of this limitation the principles of international environmental law cannot be implemented directly in the domestic arena. So like most of the country the judiciary of Bangladesh is playing a vital role to develop the application of international environmental in the domestic legal system. For instance, in India the right to life under the Constitutions has been interpreted by the judiciary as including right to sound environment. ${ }^{40}$ There is a problem that judicial remedy is only available to persons who have suffered a legal injury by reason of violation or threatened violation of his right or legally protected interest by the impugned action of the state or a public authority. Previously the role of judiciary of Bangladesh in this regard was so restrictive and the court held that aggrieved person test requires the person to be directly affected. ${ }^{41}$ But letter it is showing liberal view as regard. The court said that an aggrieved person need not suffered directly and in case of violation of fundamental rights affecting particularly the weak, downtrodden or deprived section of the community or that there is a public cause involving public wrong or public injury, any member of the public or an organization, whether being a sufferer himself or not, become a person aggrieved if it is for the realization of any if the objectives or purposes of the constitution. ${ }^{42}$ On the other hand in India this approach is much more liberal. ${ }^{43}$

The remedies available in the judiciary of Bangladesh in case of environmental dispute are mainly injunctive in nature or declarative in nature and also civil or criminal damages. In a case the High Court Division of Supreme court of Bangladesh granted an ad interim injunction on the construction of a 10 storied market in violation of the Dhaka Master Plan causing environmental obstruction to its neighborhood. ${ }^{44}$ In another case the Court granted injunction on government body to prevent them from filling up public lake as they deviated from the Master Plan. ${ }^{45}$

Unlike Indian national courts the courts of Bangladesh do not mention any of the principles of international environmental law directly. However the most remarkable case as regard the application of principles of international environmental law is Flood Action Program case where the principle of sustainable development was applied by the court indirectly in Bangladesh. In this case, Dr. Farooque challenged the validity of some flood action programs taken by the government in 1995. The main allegation of the Appellant was that the project would adversely affect and injure more than a million people by way of displacement, damage to the soil, destruction of natural habitat of fishes, flora and fauna and creating a drainage problem, threatening human health and worsening sanitation and drinking water supplies. It was alleged that the project would create environmental hazards and ecological imbalance. Accepting the contentions of the Appellant and allowing the locus standi the Appellate Division held that any encroachment to fundamental rights including right to healthy environment is amenable to judicial scrutiny under Article 102 of the Bangladesh Constitution. Justice ATM Afzal declared rather empathically, in the 'context of engaging concerns for the conservation of environment, irrespective of the locality where it is threatened any person' should be attributed a 'threshold standing' to have his grievance mitigated. Justice B. B. Roy Chowdhury made it clearer when he said "Articles 31 and 32 of our Constitution protect right to life as a fundamental right. It encompasses within its ambit, the protection and preservation of environment, ecological balance free from pollution of air and water, sanitation

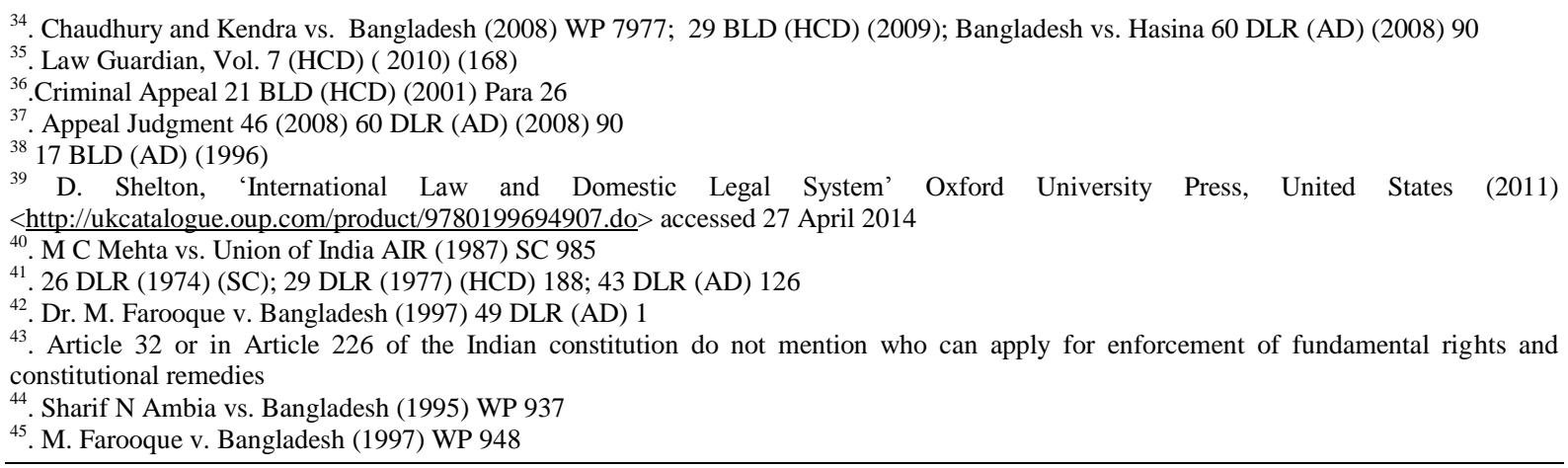


without which life can hardly be enjoyed. Any act or omission contrary thereto will be violative of the said right to life." The constitutional urge to assimilate international environmental law within the domestic sphere was vivid in this landmark case. ${ }^{46}$ Another case of Khushi Kabir and Others v. Government of Bangladesh and others $^{47}$, is also relevant in this context. It deals with commercial shrimp cultivation and its adverse effect on the socio-economic development and on sustainable development. ${ }^{48}$ A National Environment Management Action Plan (NEMAP) has been prepared identifying the key environmental issues and actions required to halt or reduce the rate of environmental degradation, to improve the natural and man-made environment, to conserve habitats and biodiversity, to promote sustainable development, and to improve qualitative indicators of human life. The NEMAP can be considered to be the first initiative towards the preparation of a National Agenda 21. The NEMAP has outlined an action plan to address the environmental issues of Bangladesh. ${ }^{49}$

A small number of Constitutions entail a constitutional duty on the citizens and on the state to save from harm and preserve the eco-systems and natural resources for the benefit of present and future generations i.e. the principle of intergenerational equity. For instance the constitution of Namibia has included such principle and said that maintenance of ecosystems, essential ecological processes and biological diversity of Namibia and utilization of living natural resources on a sustainable basis for the benefit of all Namibians, both present and future; in particular, the Government shall provide measures against the dumping or recycling of foreign nuclear and toxic waste on Namibian territory. ${ }^{50}$ But the Constitution of Bangladesh does not mention this principle directly. However, if the spirit of the Constitution is considered, this principle can be easily applied in the domestic legal system of Bangladesh. In M. Farooque V. Bangladesh and Others the petitioner BELA submitted that they represented not only the present generation but the generation yet unborn. The petitioner mentioned Minors Oposa casein which the twin concepts of 'intergenerational responsibility and 'intergenerational justice were presented by the plaintiffs to prevent the misappropriation or impairment of Philippine's rain forest. According to the Bangladeshi court, standing in the Oposa case was allowed because 'the right to a balanced and healthful ecology was a fundamental right in the Constitution of Philippine. ${ }^{51}$ But the court did not apply this principle on the ground that neither the Constitution nor the national legislation of Bangladesh explicitly mentions this principle. In another case the principle of intergenerational equity although mentioned but did not establish the precious right of this principle. ${ }^{52}$

Another principle of international environmental law is polluter pays principle which is applied by the Indian court in various cases ${ }^{53}$ but in Bangladesh there is no remarkable case as regard the application of this principle although it is incorporated by the national law the Bangladesh Conservation Act, $1995 .^{54}$

The precautionary principle aims to provide guidance in the development and application of international environmental law where there is scientific uncertainty. ${ }^{55}$ In Bangladesh this principle is considered as a guiding principle for making policy non-binding in nature. Considerable national laws have incorporated this principle as a substantive rule ${ }^{56}$ and the judiciary of Bangladesh is also applying it in various cases relating to environmental issues. In Radioactive Milk $\operatorname{cas}^{57}$ the petitioner, a potential consumer, submitted the writ petition in public interest stating that the consumption of the imported food item containing radiation level higher than the acceptable limit is injurious to public health and is a threat to the life of the people of the country. A potential customer's right to file a suit has been recognized by this case. In the Flood Action Plan case $^{58}$ the court took account of the seriousness of damage that could be caused to the environment by the project. However, the court did not apply the PP and did not bar the development project. Even though Indian Courts have accepted it as a customary law ${ }^{59}$ but Bangladeshi courts have not interested to accept it as a customary law.

46. S. M. Masum Billah, 'Constitutional analysis of right to environment' Daily Star (Dhaka, 6 June 2009 ) 121 <http://archive.thedailystar.net/law/2009/06/01/index.htm> accessed 27 April 2014

47. WP 3091 (2000) HCD

48. N. Mohammad, 'Environment and Sustainable Development in Bangladesh: A Legal Study in the Context of International Trends' $\operatorname{ICESCR}(2012) 2$

49. Supra Note 2

${ }^{50}$. Constitution of the Republic of Namibia art 95(1)

51. Jona Razzaque, 'Access to Environmental Justice Role of the Judiciary in Bangladesh'(PhD thesis, University of London) ; 49 DLR (1997) (AD) <http://www.eng-consult.com/ben/papers/paper-jona.pdf> accessed 15 April 2014

52 . Ibid, WP $300(1995)$

53. Vellore Citizen's Welfare Forum (1996) AIR (SC) 2715; M.C. Mehta (Tanneries) v. Union of India and Others (1997) 2 SCC 411

54 . Bangladesh Conservation Act 1995, s 9

55 Philippe Sands, Principles of International Environmental Law, Principles and Rules Establishing Standards (2 ${ }^{\text {nd }}$ edn, Cambridge University 2003) 267

56. Wildlife (Protection and Safety) Act 2012; Protection and Conservation of Fish Act 1950; Forest Act 1927; Bangladesh Environmental Conservation Act 1995

57 . Dr Mohiuddin Farooque v. Bangladesh and Others (1996) WP 92

${ }^{58}$. M. Farooque v. Bangladesh (1997) 49 DLR (AD) 1

${ }^{59}$. (1996) 5 SCC 647 at 658 ; (1997) 2 SCC 353; (1997) 3 SCC 715; (1997) 2 SCC 87; (1997) 2 SCC 411 
Although the Environment Impact Assessment principle and also the Harm prevention principle have been incorporated by the Bangladesh Environment Conservation Act, 1995 but there is no remarkable role of Judiciary in case of application of these principles.

\section{Conclusion}

After analyzing the entire legal framework and related cases it can be concluded that there is no direct implementation of the principles of international environmental law in Bangladesh. Although in some cases the judiciary has tried to equate by explain on different approach between the principles of international environmental law and the existing legal regime of Bangladesh but it is very much cautious to apply these principles directly in the national level. In the advancement of environmental law like many other countries the constitution of Bangladesh should incorporate the strong provisions with regard to the environmental protection and conservation so that the fundamental and recognized principles of international environmental law can be implemented in the domestic legal system very effortlessly. Another important thing is that it is high time to incorporate environmental right in the constitution of Bangladesh as one of the fundamental rights. So like many other modern constitution of the world Bangladesh should incorporate in the constitution at least some basic principles of international environmental law. However another recommendation is that Bangladesh should amend the existing environmental related laws and enact some other legislation with incorporation of these principles to adjust the changing circumstances of international regime. While a new environmental jurisprudence has emerged in Bangladesh through judicial activism but this will flourishing only when the legal framework will be strong as well.

\section{References}

[1]. Constitution of the People's Republic of Bangladesh

[2]. Interim Constitution of Nepal

[3]. Constitution of the Kingdom of Bhutan

[4]. Constitution of India

[5]. Constitution of the Republic of Namibia

[6]. Water Pollution Control Ordinance 1973

[7]. Pollution Control Ordinance 1977

[8]. National Environmental Policy 1992

[9]. Environmental Action Plan, 1992

[10]. Bangladesh Conservation Act 1995

[11]. Environmental Court Act 2000

[12]. Forest Act 1927

[13]. Protection and Conservation of Fish Act 1950

[14]. Wildlife (Protection and Safety) Act 2012

[15]. Convention on Wetlands of International Importance, especially as Waterfowl Habitat' (adopted 2 February 1971, entered into force 21 December 1975)

[16]. Convention on the Protection and Use of Transboundary Watercourses and International Lakes (adopted 17 March 1992 , entered into force 6 October 1996)

[17]. Convention on Biological Diversity (adopted 5 June 1992, entered into force 29 December 1993)

[18]. Sands P, Principles of International Environmental Law, Principles and Rules Establishing Standards (2 $^{\text {nd }}$ edn, Cambridge University 2003)

[19]. Hossain Iqbal Md, International Environmental Law Bangladesh Perspective ( $2^{\text {nd }}$ edn, Ain Prokashona 2008)

[20]. Shelton D, 'International Law and Domestic Legal System' Oxford University Press, United States (2011) <http://ukcatalogue.oup.com/product/9780199694907.do > accessed 27 April 2014

[21]. Razzaque J, 'Access to Environmental Justice Role of the Judiciary in Bangladesh'(PhD thesis, University of London) <http://www.eng-consult.com/ben/papers/paper-jona.pdf $>$ accessed 15 April 2014

[22]. Kurukulasuriya L \& Robinson Nicholas A, Training Manual on International Environmental Law (UNEP/Earthprint Publishing 2006) 23-24 <http://www.unep.org/environmentalgovernance/Portals/8/documents/training_Manual.pdf > accessed 2 February 2014

[23]. Hasan Rizwana S, APPLICATION AND REFORM NEEDS OF THE ENVIRONMENTAL LAWS IN BANGLADESH (2005) 9(85) BJL <http://www.biliabd.org/article\%20law/Vol-09/Syeda\%20Rizwana\%20Hasan.pdf> accessed 5 February 2014

[24]. Hasan Saiful G and Rahaman Ashrafur S,Principles of International Environmental Laws: Application in National Laws of Bangladesh (2013) 11 BVRJ < http://www.bv-f.org/vol_11.html > accessed 17 February 2014

[25]. Billah Masum S M, Constitutional analysis of right to environment, Daily Star (Dhaka, 6 June 2009) 121 <http://archive.thedailystar.net/law/2009/06/01/index.htm> accessed 27 April 2014

[26]. Mohammad N, Environment and Sustainable Development in Bangladesh: A Legal Study in the Context of International Trends, (International Journal of Law and Management 2011) 53(2) 